\title{
The Inheritance of Essential Diabetes Mellitus from Studies of the Synalbumin Insulin Antagonist
}

\author{
J. VALLANCE-OWEN
}

Department of Medicine, The Queen's University of Belfast, Belfast, Northern Ireland

Received May 23, 1966

\begin{abstract}
Summary. Patients with essential diabetes including prediabetes have more synalbumin antagonism to insulin than normal subjects or patients with "pancreatic" diabetes, e.g. after pancreatectomy. Thus excessive synalbumin antagonism (synalbumin positive) can be regarded as a biochemical marker to ascertain whether a given person is constituted as an essential diabetic without reference to carbohydrate intolerance. - On this premise, the genetic transmission of essential diabetes has been examined by studying the relatives of essential diabetics. The results strongly suggest that excessive synalbumin antagonism is inherited as an autosomal "dominant" character. - Ninety-seven members of nine families were studied, 39 were synalbumin negative whereas 58 were synalbumin positive, but only 16 of these latter have overt carbohydrate intolerance. A further three have spontaneous hypoglycaemia whereas the remainder are quite asymptomatic. These observations suggest that overt carbohydrate intolerance is relatively uncommon or will be a late event in many people constituted as essential diabetics.
\end{abstract}

L'hérédité du diabète sucré essentiel d'après des études de l'antagoniste synalbuminique de l'insuline.

Résumé. Les patients atteints de diabète essentiel, y compris les prédiabétiques, ont davantage d'antagonisme synalbuminique vis-à-vis de l'insuline que les sujets normaux ou les patients atteints de diabète "pancréatique" c-à-d. après pancréatectomie. L'antagonisme synalbuminique excessif (synalbumine positif) peut donc être considéré comme un critère biochimique pour déterminer si une personne donnée a une constitution de diabétique essentiel - - sans se référer à l'intolérance aux hydrates de carbone. - A partir de ceci, la transmission génétique du diabète essentiel a été examinée par l'étude des parents des diabétiques essentiels. Les résultats suggèrent fortement que l'antagonisme synalbuminique excessif se transmet comme un caractère autosomial «dominant». Quatre-vingt-dix-sept membres appartenant à neuf fa- milles ont été étudiés, 39 étaient synalbumine négatif, tandis que 58 étaient synalbumine positif, mais seulement 16 de ces derniers avajent une intolérance manifeste aux hydrates de carbone. Trois autres avaient une hypoglycémie spontanée, tandis que les autres étaient complètement asymptomatiques. Ces observations suggèrent que l'intolérance manifeste aux hydrates de carbone est relativement peu fréquente, ou qu'elle sera un évènement tardif chez beaucoup de personnes ayant la constitution de diabétiques essentiels.

Der Vererbung des essentiellen Diabetes mellitus auf Grund von Studien über den Synalbumin-Insulin-Antagonisten.

Zusammenfassung. Patienten mit essentiellem Diabetes mellitus und seinen Vorstufen weisen gegenüber Insulin einen stärkeren Synalbumin-Antagonismus auf als Normalpersonen oder Patienten mit ,, pankreatischem" Diabetes, d. h. nach Pankreatektomie. Daher kann ausgeprägter Synalbumin-Antagonismus (synalbuminpositiv) als ein biochemisches Merkmal aufgefaßt werden, das die Feststellung erleichtert, ob eine bestimmte Person die Anlage zum essentiellen Diabetes trägt, ohne Berücksichtigung einer Kohlenhydratintoleranz. - Unter. diesem Gesichtspunkt versuchten wir die genetische Übertragung von essentiellem Diabetes aufzuklären, indem wir die Verwandten von essentiellen Diabetikern untersuchten. Die Ergebnisse deuten stark darauf hin, daß ausgeprägter Synalbumin-Antagonismus als ein autosomales, ,dominantes" Charakteristikum vererbt wird. - 97 Personen aus 9 Familien wurden untersucht. 39 waren synalbumin-negativ, 58 synalbuminpositiv, doch hatten nur 16 der letzteren eine manifeste Kohlenhydratintoleranz. 3 weitere wiesen Spontanhypoglykämien auf, während die übrigen völlig symptomfrei waren. - Diese Beobachtungen weisen darauf hin, daß eine manifeste Kohlenhydratintoleranz relativ ungewöhnlich ist, bzw. erst spät im Leben vieler Personen auftritt, die die Anlage zum essentiellen Diabetes tragen.
It has long been recognised that there is a higher incidence of diabetes mellitus among the relatives of diabetics than among the rest of the population. Nevertheless, there is apparently considerable confusion regarding the mode of inheritance of this condition. After reviewing much of the available evidence Pincus and White [7] and Steinberg $[8,9]$ conclude that predisposition to diabetes is probably due to homozygosis for a recessive gene; although a number of investigators hold different views or feel that this suggestion cannot explain all the facts, remembering that the studies to date have only involved carbohydrate intolerance. Circumstantial evidence con- cerning the behaviour of the syndrome of carbohydrate intolerance suggests that, if inheritance is involved, it is the liability to develop carbohydrate intolerance which is conferred by the appropriate genotype, and thus it is not possible to study the hereditary behaviour of essential diabetes mellitus without a suitable genetic marker.

Early studies on untreated or uncontrolled insulinrequiring diabetic patients showed that their plasma inhibited the activity of insulin added in vitro [13]. It was later shown that the antagonism to insulin found in the plasma of these patients resides in the albumin fraction of the plasma proteins [14]. The whole plasma 
from normal subjects and from obese diabetics, who ordinarily do not need insulin therapy, has no measurable insulin antagonism. Nevertheless, when normal plasma is broken down into its various constituents, insulin antagonism can be detected in the albumin fraction, although this fraction is less active than that prepared from the plasma of insulin-requiring diabetics. At a concentration of $3.5 \%-5.5 \%$, which includes the physiological range, both diabetic and normal albumin completely inhibited the effect of 1000 microunits $/ \mathrm{ml}$ insulin added in vitro. At 1.25\%, however, the diabetic albumin was still highly antagonistic, whereas normal albumin was now inactive. In each instance, the antagonism is not due to the albumin itself but to some substance associated with it, hence the term -synalbumin antagonist.

Albumin has been prepared from the plasma of obese diabetic patients and from subjects with latent or prediabetes. JACkson [3] has defined "prediabetes" as "the state of a person during the period before he or she becomes plainly and clinically diabetic, in which, however, there is a latent abnormality which may show itself under certain specific conditions". At a concentration of $1.25 \%$, albumin from obese diabetics and prediabetics is antagonistic to insulin to the same extent as albumin prepared from the plasma of insulin-requiring diabetic patients, and to a considerably greater extent than normal albumin which is inactive at this concentration [16]. Moreover, patients with the diabetic syndrome, as presently defined, but suffering from definite pancreatic disease, such as acute pancratitis or haemochromatosis or who have sustained total pancreatectomy, have no increased synalbumin antagonism $[10,11]$.

Thus, essential diabetics, whether insulin-requiring; obese or prediabetic, have more antagonism to insulin associated with their plasma albumin than is found with the same plasma protein fraction from normal subjects or from "pancreatic" diabetics. These observations indicate that excessive synalbumin antagonism (synalbumin positive) can be regarded as a biochemical marker to ascertain whether or not a given individual is constituted as an essential diabetic without reference to carbohydrate intolerance. On this premise the presumed genetic transmission of essential diabetes has been examined by studying the relatives of patients suffering from this condition. The preliminary findings in four families have already been reported [18].

\section{Materials and Methods}

Subjects : 97 members of nine families were studied, these included 16 with overt diabetes mellitus.

Plasma: Venous blood 2-21/2 hours after a meal was withdrawn into a heparinised syringe from all the subjects mentioned above.

Preparation of albumin: Albumin was prepared from the plasma by the method of Desko [1] as modified by VALLANCE-OWEN [14].
An equal volume of $10 \%$ trichloroacetic acid (TCA) was added to the plasma, the supernatant after centrifugation was discarded and the precipitate washed twice with $5 \%$ TCA. The precipitate was then suspended in $1 \%$ TCA $/ 96 \%$ aqueous ethanol in a volume equal to three times the original volume of plasma. After centrifugation the extract was dialysed for 48 hours against running tap water, for a further 24 hours against two changes of distilled water and then lyophilized.

Detection of insulin antagonism : Insulin antagonism was determined by the rat diaphragm procedure previously described $[12,13]$.

The freeze-dried albumin fractions obtained were dissolved in buffer solution [2] containing glucose $0.3 \%$ $\mathrm{w} / \mathrm{v}$ to make a final concentration of $1.25 \%$, and any insoluble matter removed by centrifugation. Insulin was added to the buffer alone and to the dissolved albumin to make a final concentration of 1000 microunits $/ \mathrm{ml}$.

In any one experiment the glucose uptake of the diaphragm was determined in (a) buffer alone (basal uptake); (b) buffer plus added insulin (standard); buffer with $1.25 \%$ albumin plus added insulin. The uptake was ordinarily measured three times in $2 \mathrm{ml}$ aliquots of each solution, hemidiaphragms from three different rats being used, and the results expressed in milligrams of glucose per $100 \mathrm{ml}$ solution per $10 \mathrm{mg}$ dry weight of diaphragm over the 90 minute incubation period.

\section{Results}

Each albumin sample tested at $1.25 \%$ was either significantly antagonistic to insulin to at least the $5 \%$ level or nonantagonistic to the hormone, and as the individual observations within each group - either antagonistic or non-antagonistic - were essentially similar they have been recorded together in the family tables. The family trees are shown in Fig. 1-3 with the corresponding assay results in tables 1 and 2 .

The series of experiments recorded horizontally in these tables are units in themselves; the fact that the sensitivity of the diaphragms to insulin varies occasionally is of no consequence. The variation of responses for each horizontal series can be seen from the standard errors of the mean given in the tables.

In the 20 sibships suitable for analysis there were 75 members, of which, excluding any propositii, 38 were synalbumin positive and 26 were synalbumin negative, a ratio not differing significantly from $1: 1$ $\left(X^{2}=2.25\right)$.

As well as the 97 individual albumin samples recorded here, a further 206 separate samples have also been tested for insulin antagonism at a concentration of $1.25 \%$ - these latter were prepared from the plasma of healthy volunteers, patients with ischaemic heart disease and unselected hospital patients suffering from a variety of other conditions. 
Fig. 4 shows that the glucose uptake values above the basal level for these 303 individual samples, when tested at $1.25 \%$ against $1000 \mu \mathrm{u} / \mathrm{ml}$ insulin, and equated against the mean value of $14.0 \mathrm{mg} / 100 \mathrm{ml} /$ $10 \mathrm{mg}$ diaphragm for the standard insulin solution, have a bimodal distribution.
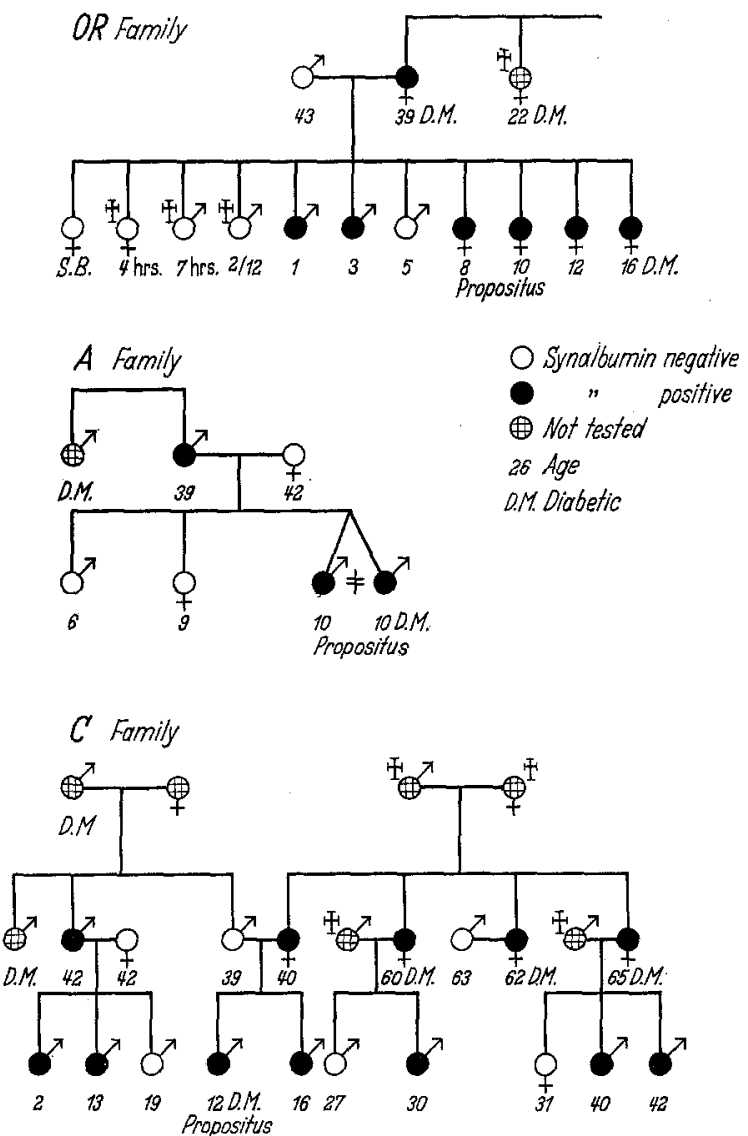

Fig. 1. Three family pedigrees showing prevalence of excessive synalbumin antagonism, The propositii in " $O$ ' $R$ " family were prediabetic when tested, but now have overt carbohydrate intolerance. Synalbumin positive $=$ albumin antagonistic to insulin at $1.25 \%$. Synalbumin negative $=$ albumin nonantagonistic to insulin at $1.25 \%$.

\section{Discussion}

This study shows a striking prevalence of excessive synalbumin insulin antagonism in consanguinous relatives of essential diabetics.

Among the 97 members of these nine families 58 were synalbumin positive whereas among 98 hospital patients selected at random only 25 were positive. This comparison could be invalidated if wide variation occurred in the proportion of positive subjects with differing age and sex - this has not so far been found.

The high familial concentration suggests genetic transmission or potent environmental causes; the latter however are unlikely as the nine families originated from different religious socio-economic groups and geographical areas. In fact these results indicate that excessive synalbumin antagonism (the state of being synalbumin positive) is inherited as an autosomal "dominant" character.

a) There are several single pedigrees covering three generations, including both synalbumin positive and synalbumin negative members, which have the typical characteristics of this type of inheritance.

Table 1. Albumin assay results for families "O'R", "A" \& "C" (Fig. 1) and "F" (Fig. 3)

\begin{tabular}{|c|c|c|}
\hline \multirow{2}{*}{$\begin{array}{l}\text { Origin and status } \\
\text { of albumin tested } \\
\text { at } 1.25 \% \\
\text { (No.) }\end{array}$} & \multicolumn{2}{|c|}{$\begin{array}{l}\text { Mean glucose uptake above basal level } \\
\pm \text { standard error of mean (mg glueose } \\
\text { per } 100 \mathrm{ml} \text { per } 10 \mathrm{mg} \text { rat diaphragm) }\end{array}$} \\
\hline & $\begin{array}{l}\text { Buffer }+100 \\
\text { microunits } / \mathrm{ml} \\
\text { insulin }\end{array}$ & $\begin{array}{l}\text { Albumin in buffer } \\
+1000 \text { micro- } \\
\text { units } / m \text { insulin } \\
\end{array}$ \\
\hline \multicolumn{3}{|l|}{ "O'R" Family } \\
\hline Antagonistic (7) & $12.34 \pm 0.98$ & $3.84 \pm 1.03$ \\
\hline Non-antagonistic (2) & $14.95 \pm 1.15$ & $13.40 \pm 0.70$ \\
\hline \multicolumn{3}{|l|}{ "A" Family } \\
\hline Antagonistic (3) & $11.67 \pm 0.32$ & $3.90 \pm 1.43$ \\
\hline Non-antagonistic (3) & $11.90 \pm 0.50$ & $12.10 \pm 0.47$ \\
\hline \multicolumn{3}{|l|}{ "C" Family } \\
\hline Antagonistic (12) & $13.00 \pm 0.46$ & $5.94 \pm 0.54$ \\
\hline Non-antagonistic (6) & $11.55 \pm 0.91$ & $11.20 \pm 0.98$ \\
\hline \multicolumn{3}{|l|}{ "F"' Family } \\
\hline Anta & $13.43 \pm 0.52$ & $5.34 \pm 0.71$ \\
\hline Non-antagonistic (9) & $12.65 \pm 0.61$ & $11.24 \pm 0.77$ \\
\hline
\end{tabular}

Amount of glucose taken up by diaphragm when no insulin is present in incubation medium.

Table 2. Albumin assay results for families "BA", "R", "B", "S" \& "Y" (Fig. 2)

\begin{tabular}{|c|c|c|}
\hline \multirow{2}{*}{$\begin{array}{l}\text { Origin and status } \\
\text { of albumin tested } \\
\text { at } 1.25 \% \\
\text { (No.) }\end{array}$} & \multicolumn{2}{|c|}{$\begin{array}{l}\text { Mean glucose uptake above basal leve } \\
\pm \text { standard error of mean (mg glucos } \\
\text { per } 100 \mathrm{ml} \text { per } 10 \mathrm{mg} \text { rat diaphragm }\end{array}$} \\
\hline & $\begin{array}{l}\text { Buffer }+1000 \\
\text { microunits/ml } \\
\text { insulin }\end{array}$ & $\begin{array}{l}\text { Albumin in buffe } \\
1000 \text { micro- } \\
\text { units/ml insulin }\end{array}$ \\
\hline \multicolumn{3}{|l|}{ "BA" Family } \\
\hline Antagonistic (4) & $14.02 \pm 0.38$ & $8.20 \pm 0.66$ \\
\hline Non-antaognistic (3) & $14.63 \pm 0.63$ & $14.30 \pm 0.76$ \\
\hline \multicolumn{3}{|l|}{ "R" Family } \\
\hline Antagonistic (4) & $12.47 \pm 1.52$ & $1.62 \pm 0.68$ \\
\hline Non-antagonistic (4) & $12.05 \pm 1.42$ & $11.48 \pm 1.81$ \\
\hline \multicolumn{3}{|l|}{ "B" Family } \\
\hline Antagonistic (5) & $12.88 \pm 1.42$ & $5.20 \pm 1.12$ \\
\hline Non-antagonistic (3) & $14.50 \pm 1.26$ & $14.16 \pm 1.32$ \\
\hline \multicolumn{3}{|l|}{ "S" Family } \\
\hline Antagonistic (5) & $13.38 \pm 0.68$ & $4.98 \pm 1.02$ \\
\hline Non-antagonistic (7) & $11.56 \pm 0.43$ & $11.52 \pm 0.54$ \\
\hline \multicolumn{3}{|l|}{ "Y" Family } \\
\hline Antagonistic (3) & $11.63 \pm 1.33$ & $1.13 \pm 0.83$ \\
\hline Non-antagonistic (1) & 12.30 & 12.40 \\
\hline
\end{tabular}

b) Synalbumin positive individuals have always had a similarly affected parent, as far as it has been possible to ascertain in these family series.

c) There is a 1:1 distribution of affected members in the sibships available for analysis. 
From the bimodal distribution two phenotypes exist in the population - synalbumin positive and synalbumin negative. This suggests inheritance of two alternative alleles at a single locus and that the

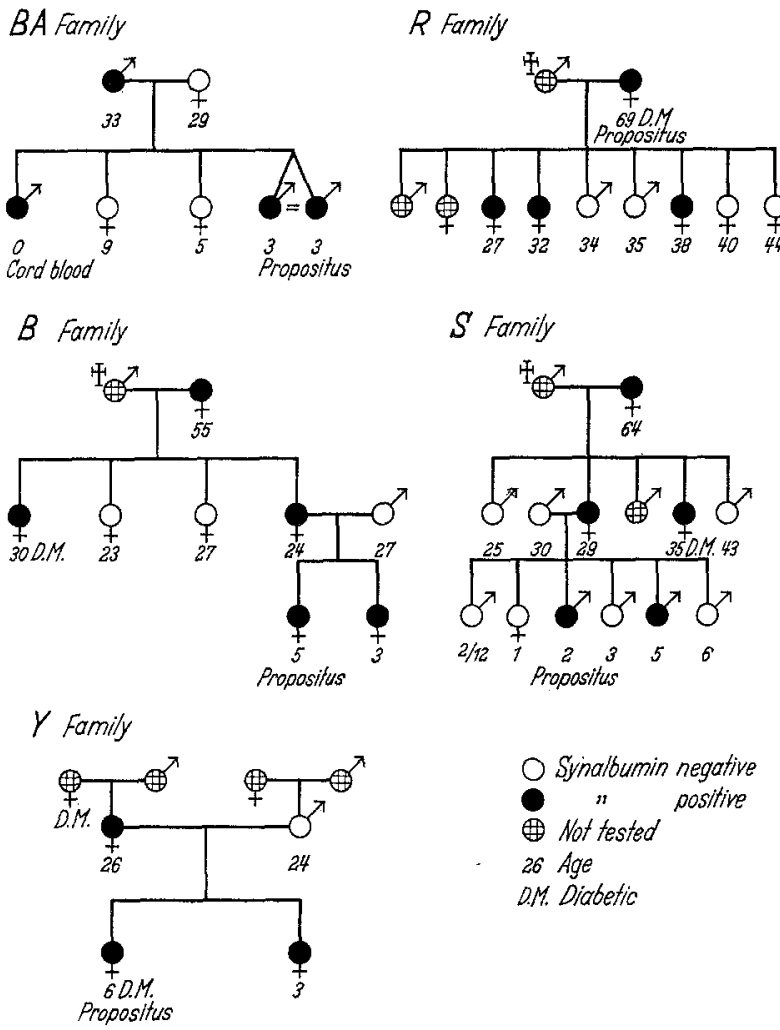

Fig. 2. Another five family pedigrees. The propositii in families "BA", " $B$ " and " $S$ " suffered from spontaneous hypoglycaemia. As well as the twins in family "BA", two other pairs of identical twins have also been found to be synalbumin positive. Also synalbumin positive mothers have had cord bloods which were synalbumin negative as well as synalbumin positive

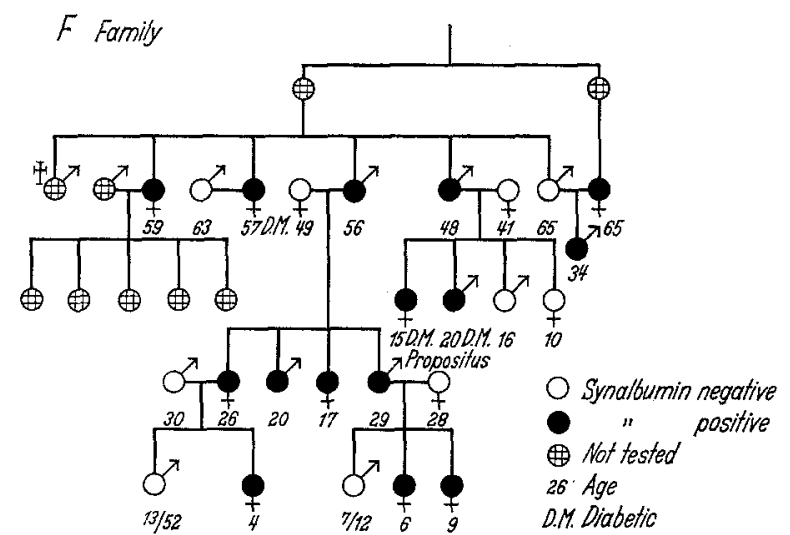

Fig. 3. One large family pedigree showing the inheritance of excessive synalbumin antagonism through three generations

division is not artificial. It also suggests that the homozygous and heterozygous members of the synalbumin positive group cannot be distinguished by the present test. Alternatively all the synalbumin positive in- dividuals are heterozygotes, the homozygous state being lethal.

Some support for the latter notion derives from the high abortion rate in diabetic pregnancies [4] and the high perinatal mortality, which is around $18 \%[5,6]$.

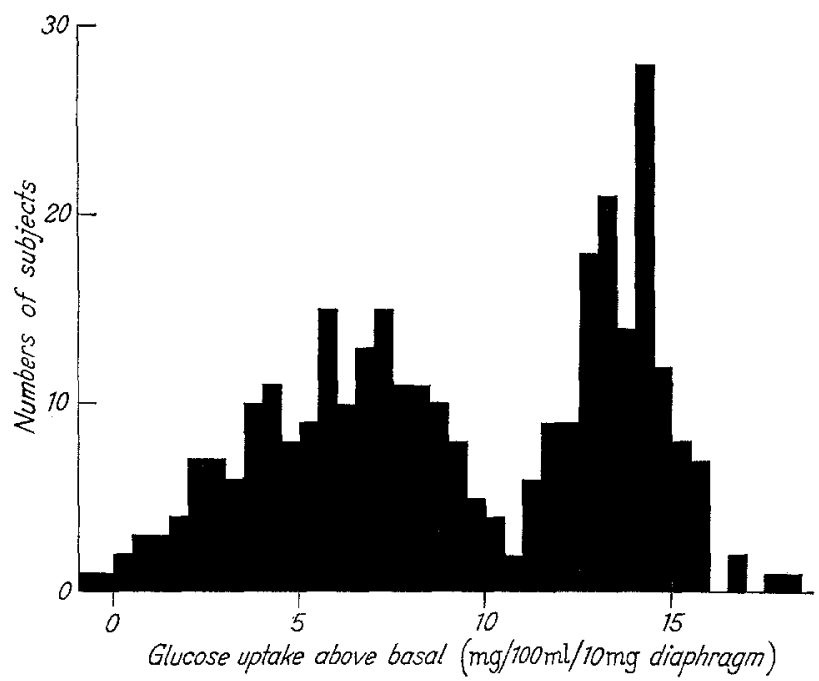

Fig. 4. Histogram showing glucose uptake values above the basal level for 303 individual albumin samples tested at $1.25 \%$ against $1000 \mu \mathrm{u} / \mathrm{ml}$ insulin These results have been standardized against our mean insulin effect at $1000 \mu \mathrm{u} / \mathrm{ml}$, which is $14.0 \mathrm{mg} / 100 \mathrm{ml} / 10 \mathrm{mg}$ diaphragm. [e.g. actual insulin $=11.0$ and insulin + albumin $=2.9$, the corrected albumin effect $=5.9$ conversely if insulin effect $=15.0$ and insulin + albumin $=8.6$, corrected albumin effect $=7.6]$

These observations indicate that there are many constituted diabetics who will never develop carbohydrate intolerance, and that there are many more people so constituted than had been previously realised. Whether or not a synalbumin positive individual, constituted as an essential diabetic, develops carbohydrate intolerance may well depend upon environmental and physiological factors, for the synalbumin antagonist is dependent upon the pituitary adrenal system $[15,17]$. In other words, the already increased antagonism can be even further increased under certain conditions, notably the growth spurt, pregnancy, infection, the menopause, mental stress for any reason, or when adrenal corticosteroids are administered. These are specific times and situations which are already well known to precipitate the state of carbohydrate intolerance in some susceptible individuals or to aggravate this symptom if it already exists.

In any event it is unsatisfactory to study the genetics of this clinical entity by merely analysing one symptom, which is itself apparently relatively uncommon in relation to a condition which has been present from birth. Hence it is not really surprising that so much confusion has existed in the field of diabetic genetics.

Acknowledgment. It is a pleasure to thank Dr. Jown Gray and Dr. DAVID Price Evans for their assistance with the genetics and the British Diabetic Association and the British Insulin Manufacturers for research grants during the course of this work. 


\section{References}

[1] Demro, J.R., H. TARVER, and A. Korner: The determination of serum albumin and globulin by a new method. J. Lab. clin. Med. 50, 728 (1957).

[2] GEY, G.O., and N.K. GEY: The maintenance of human normal cells and tumor cells in continuous culture. Amer. J. Cancer 27, 45 (1936).

[3] JACkson, W.P.U.: Prediabetes - a Synthesis. Postgrad. med. J. 35, 287 (1959).

[4] Joslin, E., H. Root, P. White and A. Marble: United States Department of Health, Education and Welfare, Public Health Service, Vital Statistics Spec. Report. 39, 705 (1958).

[5] Muller, M.: Diabetic Pregnancy and Foetal Survival in a Large Metropolitan Area. In: On the Nature and Treatment of Diabetes. LeIBEL, B. S., and G. A. Wrenshall: eds. Amsterdam, Excerpta Medica Foundation, p. 714, 1965.

[6] Oster, M.: Structural and Chemical Changes in Infants of Diabetic and Prediabetic Mothers. In: On the Nature and Treatment of Diabetes. B.S. Leibel, and G.A. Wrenshall, eds. Amsterdam, Excerpta Medica Foundation, p. 692, 1965.

[7] Pincus, G., and P. White: On the inheritance of diabetes mellitus. 1 . An analysis of 675 family histories. Amer. J. Med. Sci. 186, 1 (1933).

[8] Stemberg, A.G.: The Genetics of Diabetes: A Review. Ann. N.Y. Acad. Sci. 82, 197 (1959).

[9] - Genetics and Diabetes. In: On the Nature and Treatment of Diabetes. B.S. Leibel and G.A.
Wrenshall, eds. Amsterdam, Excerpta Medica Foundation, p. 601, 1965.

[10] VatlaNCE-Owen, J.: Diabetes Mellitus - Causation, Proc. roy. Soc. Med. 55, 207 (1962).

[11] - Synalbumin insulin antagonism and diabetes. Ciba Found. Colloq. Endocrinol. London, Churchill 15, 217 (1964).

[12] -, and B. HuRLock: Estimation of plasma insulin by the rat diaphragm. Lancet 1954 I, 68 .

[13] - and N.W. PLeAse: Plasma insulin activity in diabetes mellitus measured by the rat diaphragm technique. Lancet 1955 II, 583.

[14] - E. Dennes and P.N. CampbedL: Insulin antagonism in plasma of diabetic patients and normal subjects. Lancet 1958 II, 336.

[15] - - The nature of the insulin antagonist associated with plasma albumin. Lancet 1958 II, 696 .

[16] - and M.D. LILLEY: Insulin antagonism in the plasma of obese diabetics and prediabetics. Lancet $1961 \mathrm{I}, 806$.

[17] - - An insulin antagonist associated with plasma albumin. Lancet $\mathbf{1 9 6 1} \hat{\mathbf{I}}, 804$.

[18] -, and Ashton, W. L.: Inheritance of essential diabetes mellitus from studies of the synalbumin insulin antagonist. Diabetes 12. 356 (1963).

\section{J. VALLANCE-OWEN}

Department of Medicine

The Queen's University of Belfast

Belfast, Northern Ireland 